\begin{tabular}{|l|l|l|l|l}
\hline Int.J.Curr.Microbiol.App.Sci (2018) 7(1): 61-70 \\
$\begin{array}{l}\text { International Journal of Current Microbiology and Applied Sciences } \\
\text { ISSN: 2319-7706 Volume 7 Number 01 (2018) } \\
\text { Journal homepage: http://www.ijcmas.com }\end{array}$ \\
\hline $\begin{array}{l}\text { EXCELLENT } \\
\text { PUBLISHERS }\end{array}$
\end{tabular}

Original Research Article

https://doi.org/10.20546/ijcmas.2018.701.009

\title{
Physiological Manifestation during Seed Deterioration in Phaseolus vulgaris Germplasm
}

\author{
Chandramohan Sangh ${ }^{1 *}$ and Veena Gupta ${ }^{2}$ \\ ${ }^{1}$ ICAR-Indian Agricultural Research Institute New Delhi-110012, India \\ ${ }^{2}$ Division of Germplasm Conservation, ICAR-National Bureau of Plant Genetic Resources, \\ New Delhi-110012, India \\ *Corresponding author
}

\section{Keywords}

Accelerated ageing, Seed deterioration, French bean, Physiological

\section{Article Info}

Accepted: 04 December 2017 Available Online: 10 January 2018

A B S T R A C T

Major problem in agriculture is adequate seed storage due to difficulties in maintaining seed viability and vigour. Fifty French bean genotypes were taken to study the physiological basis of seed deterioration. The seeds were aged for $45^{\circ} \mathrm{C}$ and $100 \% \mathrm{RH}$ and physiological parameters were recorded. Moisture content ranged from $9.697 \%$ to 11.246 $\%$. There was increase in moisture content across treatments. The speed of germination differed significantly among the different treatments. The fresh seed lot recorded significantly higher speed of germination. The values for control ranged from 24.21 to 74.46.The germination of French bean germplasm varied from $84 \%$ to $100 \%$. There is a decrease in root length from control to four days of accelerated ageing. The root length ranged from $14.4 \mathrm{~cm}$ to $30.1 \mathrm{~cm}$. The control seed recorded significantly higher root length, shoot length and seedling length than the treatments with different accelerated ageing conditions. There was decrease in shoot growth from two days accelerated ageing to four days accelerated ageing Vigour index for the control seed lots ranged from 3139.20 to 7290.00 . After $72 \mathrm{~h}$ of ageing, all the varieties registered a significant decrease in vigour index I. After four days of accelerated ageing the seed vigour index I decreased drastically.

\section{Introduction}

French bean (Phaseolus vulgaris L.) is a member Leguminosae family and native of South America. It is domesticated in Mexico, Peru and Colombia about 8000 years ago (Schoonhoven and Voysest, 1991). It is widely cultivated in tropics, sub tropics and temperate regions. In India and most of the tropical Asia, it is a major vegetable crop where indigenous pulses are also preferred (Kay, 1979, Duke, 1981 and Adams, 1985). It is an herbaceous annual plant domesticated independently in ancient Mesoamerica and the Andes and now grown worldwide for its edible bean, both dry and green bean. French bean production in India and world has shown an increased trend i.e3.63 million tonnes and 19 million tonnes respectively (www.faostat.com). Most of small and marginal farmers particularly young and unemployed have involved in French bean production and increase income from these traditional crops (Ahlawat, 2008). The most common issue in agriculture is seed storage, as 
it is very difficult to maintain seed viability and vigour, specially in regions with a high humidity. In recent years, a rapid ageing method where seeds are subjected to high temperature and saturated humidity is a important technique in determining the rate of deterioration in seed storage.

The storage potential of cultivars varies within a species and associated with seed coat colour. Imbibition also leads to deacrease in seed quality there by leading to decreased seed quality in legumes (Matthews, 1980, Powell et al., 1984).First, there is a increase in leakage of solutes in seed cotyledons (Powell and Matthews, 1977), further slowly leads to more solute leakage and finally dead tissue development. The increase in solute leakage leads to increase in the electrical conductivity of seed soak water (Matthews and Powell, 1981). Maintaining good quality of seeds is a constant problem in agriculture (Ouzouline et al., 2009). Hence there is a need to develop reliable parameters for identification of seed quality loss.

The processes involved in seed ageing are complex and mechanism are not fully understood (McDonald, 1999). Several mechanisms of seed ageing are known to exist (Walters, 1998). No specific patterns were observed in studies involving physiology of seed deterioration (Cartelazzo et al., 2005, Cakmak et al., 2010, Balesevic-Tubic et al., 2011). Seed vigour is a indicator, which is based on different aspects of performance of the seed in the field (Perry, 1978; Perry, 1981) and in storage (Hampton and Coolbear, 1990).

Seed vigour is a important tool for identifying the true potential of the seed (Powell, 1988; Egli and Tekrony, 1995). Some investigators have relied on seed ageing and membrane integrity, in identifying the physiological causes of vigour differences (Powell, 1988). Seed priming can also alters the effects of ageing in French bean (Bhanuprkash et al., 2005). Although seed ageing has been the subject of research during the past few years, conclusive information on relationship between natural and accelerated ageing is rare in literature.

Studies on seed ageing of vegetative crops grown in India, particularly in French bean haven 't been undertaken. Many physiological process and interactions are linked to ageing, including genetic and change in membrane integrity cause changes in protein synthesis at germination stage (Gidrol et al., 1990) and leads to delayed germination and abnormal growth. Keeping the above points in view, the present study was undertaken to understand the physiological basis of seed deterioration at the Division of Plant Genetic Resources, ICAR-Indian Agricultural Research Institute, New Delhi.

\section{Materials and Methods}

\section{Seed source}

The study on deterioration was conducted with the fifty genotypes of French bean. The freshly harvested seeds of different French bean genotypes were obtained from the Regional Research Station, ICAR-National Bureau of Plant Genetic Resources, Shimla. Seeds without visible defects, insect damage and malformation were selected.

Fresh seeds (untreated) were subjected to artificial ageing as perISTA procedure for a period of 4 days at $45^{\circ} \mathrm{C}+100 \%$ RH. Samples were collected at 2, 3, and 4 days interval for seed quality studies.

\section{Moisture determination}

Moisture was determined by the gravimetric method (ISTA, 1993) at $130+/-5^{\circ} \mathrm{C}$ in an oven (High constant temperature oven method). 


\section{Seed germination}

The laboratory germination test was done as per the ISTA (1993) rules using between paper methods.

Twenty five seeds in 10replications were allowed to germinate at temperature of $25^{\circ} \mathrm{C}$ up to 9 days. The germination counts were recorded on 5th and 9th day and percent germination was expressed on normal seedling basis.

\section{Speed of germination}

The germination speed index was calculated by using the formula given by Czabator, (1962).

\section{Root length $(\mathrm{cm})$}

From the standard germination test, ten normal seedlings from each treatment in four replications were randomly selected on the day of final count.

The length of root was measured from collar region to tip of the primary root of the seedling and expressed in centimeters.

\section{Shoot length (cm)}

From the standard germination test, ten normal seedlings from each treatment in four replications were randomly selected on the day of final count. The length of shoot was measured from collar region to the tip of shoot of the seedling and expressed in centimetres.

\section{Seedling Vigour Index-I}

The vigour index I was determined by multiplying the percentage germination and total seedling length (Abdul Baki and Anderson, 1982) Vigour index I = germination percentage $\mathrm{x}$ (Root length + shoot length).

\section{Data analysis}

The data analysis was performed using XLSTAT trial version and SPSS Software

\section{Results and Discussion}

\section{Effect of deterioration on seed quality related to physiological parameters}

\section{Moisture content}

Initial moisture content of the French bean germplasm was done by gravimetric method and results were expressed in percentage. Minimum moisture was present in EC-500336 with a value of $9.697 \%$ and maximum moisture was present in JAWALA with a value of $11.246 \%$. The average moisture content was observed as $10.41 \%$ with standard error and standard deviation 0.049 and 0.353 respectively (Table 1 ).

The initial moisture content differed significantly between the different accelerated ageing treatments. The moisture content among French bean genotypes varied significantly under accelerated conditions. The increase in moisture content was observed during ageing. The minimum moisture content was increased from $9.697 \%$ in control to $12.219 \%$ in four days accelerated ageing conditions. The moisture content in two days accelerated ageing ranged from $10.422 \%$ to $16.655 \%$. There was also increase in moisture content in three days accelerated ageing condition from $11.008 \%$ to $23.130 \%$. The moisture content was greatly increased in four days accelerated ageing conditions, which ranged from $12.219 \%$ to $44.474 \%$. The average moisture content present in control, two days, three days and four days accelerated ageing was $10.40 \%, 11.90 \%, 13.41 \%$ and $16.60 \%$ respectively. Among the exotic collection the highest moisture content was $10.67 \%$ in EC-398563 and lower moisture 
content was $9.70 \%$ in EC-500336. Among the indigenous collections highest moisture content was $11.03 \%$ in IC-258365 and lowest moisture content in $9.83 \%$ in IC-448994. In case of local check accessions moisture content ranged from $10.07 \%$ to $11.25 \%$.

Statistical analysis showed that there is significant difference between the treatments with $\mathrm{p}$ value $<0.001$ at 0.01 level. Tukeys HSD showed that, significant difference was found between control and two days $(\mathrm{p}=0.044)$, three days $(\mathrm{p}<0.001)$ and four days $(\mathrm{p}<0.001)$ accelerated ageing treatments. Significant difference was also found between two days and control $(\mathrm{p}=0.044)$, three days $(\mathrm{p}=0.042)$ and four days $(\mathrm{p}<0.001)$ accelerated ageing treatment. Tukeys HSD was observed between three days and control $(\mathrm{p}<0.001)$, two days $(p=0.042)$ and four days $(p<0.001)$ accelerated ageing treatment. Tukeys HSD was also observed between four days and control $(\mathrm{p}<0.001)$, two days $(\mathrm{p}<0.001)$, three days $(\mathrm{p}<0.001)$ accelerated ageing treatment.

\section{Germination percentage}

Initial germination test was done on paper method. The germination of French bean germplasm varied from $84 \%$ to $100 \%$ germination. The average germination percentage was found to be $98.88 \%$ with standard error 0.412 (Table 1).

The initial germination per cent differed significantly among the different treatments. The fresh seed lot recorded significantly higher germination per cent than the treatments. There was decrease in germination from control to second, third and four days of accelerated ageing. On second day of accelerated ageing minimum germination recorded was $44 \%$ while some of the genotypes maintained good germination. On third day of treatment few of accessions have reduced germination percent. On fourth day of treatment germination was drastically reduced and even few accession dead. Few of the germplasm were able to withstand the treatment and were alive indicating good storability of seeds.

ANOVA showed statistically significant difference between the treatments at 0.05 level of significance. Tukeys HSD was observed between control and two days $(\mathrm{p}=0.027)$, three days $(p<0.001)$ and four days $(p<0.001)$ of accelerated ageing treatment.

\section{Effect of accelerated ageing on Speed of germination in French bean genotypes}

The speed of germination differed significantly among the different treatments. The fresh seed lot recorded significantly higher speed of germination. The values for control ranged from 24.21 to 74.46. However the speed of germination did not differ significantly for two days accelerated ageing treatment, which almost similar i.e. the value ranged from 22.25 to 72.50 . The speed of germination drastically reduced for three days from 1.25 to 49.17 and on four days of accelerated ageing the speed of germination was minimum. Out of 50 French bean germplasm, the genotypes showed all the three types of storage behaviour.

ANOVA showed statistically significant difference between the treatments at 0.05 level of significance. Tukeys HSD was observed between control and three days AA $(\mathrm{p}<0.001)$ and four days $(\mathrm{p}<0.001)$ of accelerated ageing treatment. Tukeys HSD was non-significant in control and two days accelerated ageing treatment

In control minimum and maximum speed of germination was found in IC-258365 and IC037138 respectively. On two days of accelerated ageing minimum and maximum speed of germination was found in IC-258365 
and IC-037138 respectively. However from three days of accelerated ageing there was reduction in speed of germination. Minimum and maximum speed of germination was found in IC-329154 and IC-262839 respectively. On fourth day of accelerated ageing the maximum speed of germination was found in IC-037138. Since many of the accessions did not germinate on fourth day of accelerated ageing indicating low storability of French bean accessions. There is a large reduction in speed of germination from control to four days of accelerated ageing and even in some accessions it was reduced to zero indicating no germination.

\section{Effect of accelerated ageing on Root length in French bean genotypes}

There was significant difference between root length in fresh and aged French bean accessions. There is a decrease in root length from control to four days of accelerated ageing. In control the minimum root length was $14.4 \mathrm{~cm}$ observed in IC-328372 and maximum root length was $30.1 \mathrm{~cm}$ in IC415517 , with a mean root length of $22.78 \mathrm{~cm}$. In two days accelerated ageing the minimum root length was $13.6 \mathrm{~cm}$ observed in IC328372 and maximum root length was 25.5 $\mathrm{cm}$ observed in IC-415517, with a mean root length of $19.98 \mathrm{~cm}$. In three days accelerated ageing the minimum root length was 11.571 $\mathrm{cm}$ observed in IC-328372 and maximum root length was $22.8 \mathrm{~cm}$ in IC-415517, with a mean root length of $18.393 \mathrm{~cm}$. In four days accelerated ageing the minimum root length was $0 \mathrm{~cm}$ which means seeds did not germinate and were dead and maximum root length was $23 \mathrm{~cm}$ in IC-018149, with a mean root length of $10.051 \mathrm{~cm}$ (Table 1).

ANOVA showed statistically significant difference between the treatments at 0.05 level of significance. Tukeys HSD was observed between control and three days AA $(\mathrm{p}<0.001)$ and four days $(\mathrm{p}<0.001)$ of accelerated ageing treatment. Tukeys HSD was observed between two days and four days $(\mathrm{p}<0.001)$ of accelerated ageing treatment. Tukeys HSD was observed between three days and control $(\mathrm{p}<0.001)$, and four days $(\mathrm{p}<0.001)$ accelerated ageing treatment. Tukeys HSD was observed between four days and control $(\mathrm{p}<0.001)$, two days $(\mathrm{p}<0.001)$ and three days $(p<0.001)$ accelerated ageing treatment.

\section{Effect of accelerated ageing on shoot length in French bean genotypes}

The final shoot length differed significantly among the different treatments of accelerated ageing. The fresh seed lot recorded significantly higher shoot length than the treatments with different accelerated ageing conditions.

ANOVA showed statistically significant difference between the treatments at 0.05 level of significance. Tukeys HSD was observed between control and three days AA $(\mathrm{p}<0.001)$ and four days $(\mathrm{p}<0.001)$ of accelerated ageing treatment. Tukeys HSD was observed between two days and four days $(\mathrm{p}<0.001)$ of accelerated ageing treatment. Tukeys HSD was observed between three days and control $(p<0.001)$, and four days $(p<0.001)$ accelerated ageing treatment. Tukeys HSD was observed between four days and control $(\mathrm{p}<0.001)$, two days $(\mathrm{p}<0.001)$ and three days $(\mathrm{p}<0.001)$ accelerated ageing treatment. The shoot length was more in case of control than treatment. The minimum shoot growth was $13.70 \mathrm{~cm}$ in IC-258365 and maximum shoot growth was $50.50 \mathrm{~cm}$ in IC-043562. There was decrease in shoot growth from two days accelerated ageing to four days accelerated ageing. The minimum shoot growth in two days accelerated ageing was $13.00 \mathrm{~cm}$ in IC258365 and maximum shoot growth was $32.80 \mathrm{~cm}$ in EC-500250 with an average shoot length of $23.00 \mathrm{~cm}$. 
Table.1 Descriptive statistics of various physiological parameters in French bean germplasm

\begin{tabular}{|c|c|c|c|c|c|c|c|}
\hline \multirow{5}{*}{  } & & Min. & Max. & Mean & Std. Error & $\begin{array}{c}\text { Std. } \\
\text { Deviation }\end{array}$ & Variance \\
\hline & Control & 9.697 & 10.246 & 10.40 & 0.0455 & .322 & .104 \\
\hline & $\begin{array}{l}\text { Two Days } \\
\text { AA }\end{array}$ & 10.422 & 16.655 & 11.90 & 0.189 & 1.342 & 1.803 \\
\hline & $\begin{array}{l}\text { Three Days } \\
\text { AA }\end{array}$ & 11.008 & 23.130 & 13.41 & 0.267 & 1.889 & 3.572 \\
\hline & $\begin{array}{l}\text { Four Days } \\
\text { AA }\end{array}$ & 12.219 & 44.474 & 16.60 & 0.727 & 5.142 & 26.446 \\
\hline \multirow{4}{*}{  } & Control & 24.210 & 74.460 & 46.640 & 1.599 & 11.313 & 127.985 \\
\hline & $\begin{array}{l}\text { Two Days } \\
\text { AA }\end{array}$ & 22.250 & 72.500 & 44.680 & 1.599 & 11.313 & 127.985 \\
\hline & $\begin{array}{l}\text { Three Days } \\
\text { AA }\end{array}$ & 1.25 & 49.166 & 29.737 & 1.804 & 12.756 & 162.739 \\
\hline & $\begin{array}{l}\text { Four Days } \\
\text { AA }\end{array}$ & .00 & 39.67 & 11.0462 & 1.875 & 13.261 & 175.859 \\
\hline \multirow{4}{*}{ 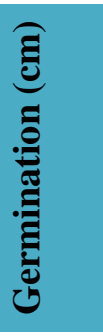 } & Control & 84 & 100 & 98.88 & .413 & 2.918 & 8.516 \\
\hline & $\begin{array}{l}\text { Two Days } \\
\text { AA }\end{array}$ & 44 & 100 & 86.24 & 2.146 & 15.176 & 230.325 \\
\hline & $\begin{array}{l}\text { Three days } \\
\text { AA }\end{array}$ & 5 & 98 & 65.97 & 3.664 & 25.911 & 671.361 \\
\hline & $\begin{array}{l}\text { Four Days } \\
\text { AA }\end{array}$ & 0 & 88 & 29.99 & 4.687 & 33.140 & $1.098 \mathrm{E} 3$ \\
\hline \multirow{4}{*}{ 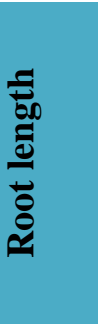 } & Control & 14.400 & 30.100 & 22.278 & .353 & 2.498 & 6.244 \\
\hline & $\begin{array}{l}\text { Two Days } \\
\text { AA }\end{array}$ & 13.600 & 25.500 & 19.980 & .2791 & 1.973 & 3.895 \\
\hline & $\begin{array}{l}\text { Three Days } \\
\text { AA }\end{array}$ & 11.571 & 22.800 & 18.393 & .299 & 2.114 & 4.471 \\
\hline & $\begin{array}{l}\text { Four Days } \\
\text { AA }\end{array}$ & .000 & 23.000 & 10.051 & 1.215 & 8.595 & 73.889 \\
\hline \multirow{4}{*}{ 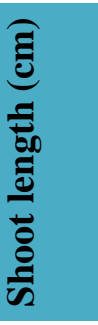 } & Control & 13.700 & 50.500 & 26.137 & .928 & 6.563 & 43.073 \\
\hline & $\begin{array}{l}\text { Two Days } \\
\text { AA }\end{array}$ & 13.000 & 32.800 & 22.997 & .760 & 5.379 & 28.935 \\
\hline & $\begin{array}{l}\text { Three Days } \\
\text { AA }\end{array}$ & 10.000 & 30.100 & 20.367 & .713 & 5.048 & 25.484 \\
\hline & $\begin{array}{l}\text { Four Days } \\
\text { AA }\end{array}$ & .000 & 27.600 & 10.506 & 1.408 & 9.956 & 99.129 \\
\hline \multirow{4}{*}{ 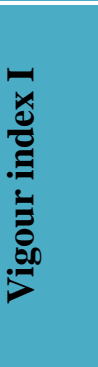 } & Control & 3139.20 & 7290.00 & 4783.19 & 112.06 & 784.471 & $\begin{array}{c}615395.68 \\
1\end{array}$ \\
\hline & $\begin{array}{l}\text { Two Days } \\
\text { AA }\end{array}$ & 1698.40 & 5030.00 & 3702.16 & 129.12 & 903.893 & $\begin{array}{c}817024.21 \\
8\end{array}$ \\
\hline & $\begin{array}{l}\text { Three Days } \\
\text { AA }\end{array}$ & 135.00 & 4351.00 & 2596.87 & 167.16 & 1170.17 & $\begin{array}{c}1369318.9 \\
51\end{array}$ \\
\hline & $\begin{array}{l}\text { Four Days } \\
\text { AA }\end{array}$ & .00 & 3701.25 & 914.71 & 160.80 & 1125.64 & $\begin{array}{c}1267070.2 \\
33\end{array}$ \\
\hline
\end{tabular}


The minimum shoot growth in three days accelerated ageing was $10.00 \mathrm{~cm}$ in IC329154 and maximum shoot growth was $30.10 \mathrm{~cm}$ in EC-500336 with an average shoot length of $20.37 \mathrm{~cm}$. The maximum shoot growth in four days accelerated ageing was observed in EC-500336 with $27.60 \mathrm{~cm}$ and average shoot length was $10.506 \mathrm{~cm}$. Since 22 accessions were dead because of accelerated ageing, there was no root and shoot growth (Table 1).

Effect of accelerated ageing on seedling length in French bean genotypes

The initial seedling length differed significantly among the different treatments. The fresh seed lot recorded higher seedling length than the treatments with different accelerated ageing conditions. In fresh seed lot the minimum seedling growth was 32.70 $\mathrm{cm}$ observed in IC-258365 and maximum was $72.90 \mathrm{~cm}$ in IC-043562. The mean seedling growth of control was $48.42 \mathrm{~cm}$. In two days accelerated ageing treatment the minimum seedling growth was $31.70 \mathrm{~cm}$ in IC-258365 and maximum seedling growth was $56.65 \mathrm{~cm}$ observed in IC-415517. The average seedling growth was $42.98 \mathrm{~cm}$. The minimum seedling growth in three days accelerated ageing treatment was $27.00 \mathrm{~cm}$ observed in IC329154 , the maximum seedling growth was $50.80 \mathrm{~cm}$ observed in IC-415517. The average seedling growth in three days accelerated ageing condition was $38.76 \mathrm{~cm}$. The minimum seedling growth in four days accelerated ageing treatment was $0.00 \mathrm{~cm}$ as most of the germplasm were dead due to the treatment, the maximum seedling growth was $44.90 \mathrm{~cm}$ observed in EC-500336. The average seedling growth in four days accelerated ageing condition was $20.56 \mathrm{~cm}$.

ANOVA showed statistically significant difference between the treatments at 0.05 level of significance. Tukeys HSD was observed between control and two days AA $(\mathrm{p}<0.043)$, three days AA $(\mathrm{p}<0.000)$ and four days $(\mathrm{p}<0.001)$ of accelerated ageing treatment. Tukeys HSD was observed between two days and control $(\mathrm{p}=0.043)$ and four days $(p<0.001)$ of accelerated ageing treatment. Tukeys HSD was observed between three days and control $(\mathrm{p}<0.001)$ and four days $(\mathrm{p}<0.001)$ accelerated ageing treatment. Tukeys HSD was observed between four days and control $(\mathrm{p}<0.001)$, two days $(\mathrm{p}<0.001)$ and three days $(\mathrm{p}<0.001)$ accelerated ageing treatment.

Effect of accelerated ageing on seedling vigour index-I in French bean genotypes

There was significant difference between seedlings in fresh and treated seeds under different accelerated ageing condition. The vigour index $\mathrm{I}$ is the product of per cent germination and total seedling length. Vigour index for the control seed lots ranged from 3139.20 to 7290.00 . The maximum vigour index was 5030.00 recorded in variety EC398536 and minimum vigour index was 1698.40 after two days accelerated ageing. The maximum vigour index at three days accelerated ageing was 4351.00 observed in EC-500528 and minimum vigour index was 135.00 observed in IC-329154. After $72 \mathrm{~h}$ of ageing, all the varieties registered a nonsignificant decrease in vigour index I. After four days of accelerated ageing the seed vigour index I decreased drastically, since most of the accessions were dead because of treatment. The maximum seed vigour index after four days accelerated ageing was 3701.25 and observed in EC-500528. As the ageing duration increased further, all the accessions registered a significantly lower vigour index I (Table 1).

ANOVA showed statistically significant difference between the treatments at 0.05 level of significance. Tukeys HSD was 
observed between control and two days AA $(\mathrm{p}<0.001)$, three days AA $(\mathrm{p}<0.001)$ and four days $(\mathrm{p}<0.001)$ of accelerated ageing treatment. Seed ageing affected seed germination, normal seedlings, root length, shoot length, total seedling length, seedling vigour indices, mean germination time, and seedling growth rate. Although seeds in control had no effect on germination, but seeds aged for four days onwards (2, 3 and 4 DAA) showed significant decline in germination when compared to control. French bean seeds aged naturally for 6 months maintained viability as that of fresh seeds (Pandey, 1989). Similarly, reduction in germination speed, seedling length and weight, seedling vigor indices were also noticed in aged (2 DAA to 4 DAA) seeds. Loss in onion seed viability and vigour related parameters upon increasing accelerated ageing duration from three to fifteen days was reported and this might be due to cellular damage under prolonged ageing leading to failure germination (Bhanuprakash et al., 2010). Similar observations in relation to artificial ageing in various crops were noticed by Mc Donald (1999)

Loss of seed germinability following natural ageing (or) accerlated ageing has been attributed to a series of metabolic defects that accumulate in embryonic and non-embryonic structures (Osborne, 1983). Ageing in French bean seeds induced membrane degradation, protein denaturation, and destruction of electron transport system of oxidative phosphorylation (Pandey, 1989) Wilson and Mc Donald (1986) observed a lipid peroxidation during ageing and proposed a model in relation to its effect on germination with respect to lipid peroxidation during seed ageing and its effect on seed germination. Changes that are associated with membrane permeability and its influence in seed germination and viability was reported by Veselova and Veselovsky (2002). Further in our findings, decrease in number of normal seedlings, decline in vigor indices like germination rate, germination index, seedling vigor index were also noticed due to seed ageing. With increase in ageing from 2 to 4 days the number of normal seedlings was reduced gradually. The speed of germination was also increased because ageing increased length of time to reach $50 \%$ germination. This might be due to stronger inhibitory effects during seed ageing (Sara and Elena. 2011). Among the longevity parameters used to study the ageing, the length of time required for germination is the measure of the onset of viability loss and could be a useful parameter.

Estimation of seedling vigour indices is an important seed quality parameter as reported by Abdul Baki (1980) in various crops. In our investigation seed ageing affected seedling vigor also. Due to accelerated ageing (2 DAA on wards) progressive decline in seedling vigor indices when compared to fresh seed lot was noticed. This might be due to decrease in total seedling length under ageing conditions. Marked reductions in seedling weight were also noticed due to ageing when compared to unaged. When compared to unaged. Seed ageing inhibits cell expansion more strongly than cell division because of this root elongation will be affected (Holmfridur et al., 2009). Reductions in shoot fresh weight and germination speed in French bean seeds stored for one year and two year under ambient conditions was reported by Pandey, 1989. Successful crop stand establishment requires high quality seeds having full germination potential with rapid and uniform seedling emergence. Loss in seed quality that occurs during all process, from maturation in the field to storage, leads to seed deterioration. Storage of French bean seeds under ambient, hot and humid conditions is very problematic since these conditions deteriorate seed quality faster. 
Accelerated aged seeds for a period of 2 days (2DAA) maintained same vigour and viability as that of fresh seeds. However increase in ageing duration reduced the viability and vigour progressively with increment in ageing viz., 3 and 4 DAA. Further ageing beyond 2 DAA resulted in loss of seed viability accompanied with loss of seed vigour, as seen by the decreased $\%$ of vigorous seedlings with increased ageing duration. As the vigour decreased, the germination was delayed and staggered. This in turn led to decrease in root length, shoot length, seedling vigour index, seedling weight, and seedling-vigour. Seeds from control showed higher mean germination time, higher germination percentage, seedling vigour and vigour index I. Some of the good storers identified are BASPA, EC-100098, EC-398536, EC500250, EC-500275, EC-500336, EC-500522, EC-500528, EC-500577, IC-037138, IC047655, IC-258365, IC-258395, IC-328372, IC-361547, IC-398563, IC-415517.

\section{References}

Abdul-Baki, A.A. and Anderson, D.J., 1982. Vigour determination in soybean seed by multiple criteria 1. Crop Sci.13:630633.

Abdul-Baki, A.A., 1980. Biochemical aspects of seed vigour. Hort. sci. 15:761-765.

Adams, M.W., 1985. Common bean (Phaseolus vulgaris L.). In: Summerfield RJ, Roberts EH, eds. Gr. Leg. Cr., London, UK: Collins, 433476.

Ahlawat, I.P.S., 2008. French Bean, In Agronomy - Rabi Crops pp 1-4 (book chapter in national science digital library).

Balesevic-Tubic, S., Miladen, T., Dordevic, V.U.K., Zorica, N., Jonel, S. andVojin, D., 2011. Changes in soybean seeds as affected by accelerated and natural ageing. Romanian Biotechnological
Letters. 16 (6): 6740-6747.

Bhanuprakash, K., Yogeesha, H.S. and Arun, M.N., 2010. Physiological and biochemical changes in relation to seed quality in ageing Bell pepper. Indian J. of Agricultural sciences. 80 (9): 9-11.

Bhanuprakash, K., Yogeesha, H.S., Arun, M.N. and Naik, L.B., 2005. Studies on seed quality in relation to ageing and priming in French bean in proceeding of the $4^{\text {th }}$ International Food Legume Research Conference, New Delhi, India, pp18-22.

Cakmak, T., Atici, O., Agar, G. andSunar, S., 2010. Natural ageing-related biochemical changes in alfalfa (Medicago sativa L.) seeds stored for 42 years. Int. J. Plant Sci. 1 (1): 001-006.

Cartelazzo, A.L., Coutinho, J. andGranjeiro, P.A., 2005. Storage and ageing of French beans (Phaseolus vulgaris L.) Effect on seed viability and vigour. Braz. J. Morphol. Sci.22 (2): 121-128.

Czabator, F. J., 1962. Germination value: An index combining speed and completeness of pine seed germination. Forest Science. 8: 386 - 395.

Duke, S.H., Kakefuda, G. and Harvey, T., 1983.Differential leakage of intercellular substances from imbibing soyabean seeds. Plant Physiol. 72: 919924.

Egli, D.B. and Tekrony, D.M., 1995. Soybean seed germination, vigour and field emergence. Seed Sci. Technol. 23: 595607.

FAOSTAT, 2010: http://faostat.fao.org/site/567/default.as px\#ancor.

Gidrol, X., Noubhani, A. and Pradet, A., 1990. Biochemical changes induced by accelerated ageing in sunflower seeds. Physiologia Plantarum. 80: 598-604.

Hampton, J. G and Coolbear, P., 1990. Potential versus actual seed performance - can vigour testing 
provide an answer? Seed Sci. Technol. 18:215-228.

Holmfridur, S., Feng, Y. and Yiyong, Z., 2009. Seed ageing induced inhibition of germination and post germination root growth is related to lower activity of plasma membrane ATPase in maize roots. J. plant physiol.166: 128-135.

ISTA, 1993. International rules for seed testing. Seed Sci. Technol, 21: 1-298.

Kay, D.E., 1979. Food legumes. Tropical Products Institute, London. Crop and Product Dig., 3: 124-176.

Matthews, S. and Powell, A.A., 1981.The controlled deterioration test. In Handbook of Vigour Test Methods (ed. DA Perry). International Seed Testing Association, Zurich 49-56.

Matthews, S., 1980. Controlled deterioration test a new vigour test for crop seeds. In Hebbletwaite, PD (Ed). Seed production. London Butterworths 647660.

McDonald, M.B., 1999. Seed deterioration: physiology, repair and assessment. Seed Sci Technol. 27: 177-237.

Osborne, D.J., 1983. Biochemical control systems operating in the early hours of germination. Indian $J$ of botany. 61: 3568-3577.

Ouzouline, M., Tahani, N., Demandre, C., Amrani, A.E., Benhassaine-Kesri, G. andSerghini, H., 2009. Effects of accelerated ageing upon the lipid composition of seeds from two wheat varieties from Morocco. Grasas y Aceites. 60(4): 367-374.

Pandey, D.K., 1989. Ageing of French bean seeds at ambient temperatures in relation to vigor and viability. Seed sci technol. 10:81-102.

Perry, D.A., 1978. Report of Vigour Test Committee 1974-1977. Seed Sci. Technol. 6: 159-181.

Perry, D.A., 1981. Introduction In: Handbook of vigour test methods, 3-7, ISTA. Zurich, Switzerland

Powell, A.A. and Matthews, S., 1977. Deteriorative changes in pea seeds (Pisum sativum L.) stored in humid or dry conditions. J. Exp. Bot. 28: 225234.

Powell, A.A., 1988. Seed vigour and field establishment. Adv. in Res. and Tech. of seeds. 11: 29-80.

Powell, A.A., Matthews, S., Oliveira, M.D.A., 1984. Seed quality in grain legumes. Adv. App. Biol. 10: 217-285.

Sara, M. and Elena, E., 2011. Biochemical changes induced in seeds of Brassicaceae wild species during ageing. Actaphysiol plant.6:251-292.

Schoonhoven and Voyset, 1991. Common beans: Research for crop improvement. Centro Int. de Agric Tropical. pp. 1827.

Veselova, T.V. and Veselovsky, V.A., 2002. Investigation of atypical germination changes during accerlated ageing of pea seeds. Seed Sci. Technol. 31:517-530.

Walters, C., 1998. Understanding the mechanisms and kinetics of seed ageing. Seed Sci. Res. 8: 223-244.

Wilson, D.O. and McDonald, M.B., 1986.The lipid peroxidation model of seed aging. Seed Sci. Technol. 14: 269-300.

\section{How to cite this article:}

Chandramohan Sangh and Veena Gupta. 2018. Physiological Manifestation during Seed Deterioration in Phaseolus vulgaris Germplasm. Int.J.Curr.Microbiol.App.Sci. 7(01): 61-70. doi: https://doi.org/10.20546/ijcmas.2018.701.009 